Malik, A. \& Ubaidillah, M. (2020). Students critical-creative thinking skill: A multivariate analysis of experiments and gender, International Journal of Cognitive Research in Science, Engineering and Education (IJCRSEE), (8), Special issue of Current Research and Trends in Cognitive Sciences 2020, 49-58.

Original scientific paper

UDK:

Received: September, 17.2020

Revised: November, 27.2020.

Accepted: December, 02.2020.

doi: 10.23947/2334-8496-2020-8-SI-49-58

\title{
Students Critical-Creative Thinking Skill: A Multivariate Analysis of Experiments and Gender
}

\author{
Adam Malik ${ }^{1 *}$, Mujib Ubaidillah ${ }^{2}$

\begin{abstract}
1Department of Physics Education, UIN Sunan Gunung Djati Bandung, Indonesia, e-mail: adammalik@uinsgd.ac.id
\end{abstract} \\ 2Department of Biology Tadris, IAIN Syekh Nurjati Cirebon, Indonesia, e-mail: mujib_ubaidillah@syekhnurjati.ac.id
}

\begin{abstract}
Students' ability to practice several thinking skills is one of the problems common in today's learning. Therefore, this research aims to describe the improvement of students' critical-creative thinking skills through a multivariate analysis of the experiment model and gender. The experiment models used in this research are the Multiple Skill Laboratory Activity Model (MSLAM) and Higher Order Thinking Laboratory (HOT Lab), with gender, considered as a factor influencing a successful learning process. Research method was a quasi-experiment with data obtained from 328 respondents from five different universities in Indonesia and analyzed using the multivariate tests. The results showed that the experiment model affected the learning outcomes more than genders. Furthermore, the Multiple Skill Laboratory Activity Module proved to improve students' critical and creative thinking skills better than the Higher Order Thinking Laboratory. This study expected to provide a comparison in determining the types of suitable experiments for learning at colleges and schools.
\end{abstract}

Keywords: critical, creative, MSLAM model, HOT Lab.

\section{Introduction}

The critical thinking skills (CrTS) and creative thinking skills (CvTS) are important abilities associated with education in this $21^{\text {st }}$ century. Several studies carried out in accordance with these skills showed that they were essential to students achievement (Bean, 2011; Pantiwati, 2013; Quieng et al., 2015; Seymour et al., 2003). CrTS and CvTS are also used in civil society, with students adopting to the new norms of global information.

Furthermore, studies have also been carried out on the learning process that practiced the use of CrTS and CvTS. According to these studies, these skills are practiced using a specific related model of teaching (Bustami and Corebima, 2017; Fuad et al., 2017; Hadi et al., 2018; Malik et al., 2020; Malik et al., 2019; Martaida et al., 2017; Muhlisin et al., 2016; Nasir, 2018; Nugraha et al., 2016; Saputri et al., 2019; Sari et al., 2018; Seranica et al., 2018; Suardana et al., 2018; Wang et al., 2015; Zaini et al., 2018). In these studies, students' ability increased significantly with the design of specific activities and purposive tasks for effective learning. The studies carried out by (Hastuti et al., 2018; Nugraha et al., 2016; Saputri et al., 2019; Weatherspoon et al., 2015) showed an increase in CrTS and CVTS by using the learning media. This result also showed that student whose used learning media have higher CrTS and CvTS compared to those that did not use it, because it made them more active while following the process. Besides, learning media was more interesting, which increased their interest and focus. However, another research showed that student achievement of CrTS and CvTS can be optimized using the laboratory activity or an experiment learning (Lisdiani et al., 2019; Malik et al., 2018; Setiawan et al., 2018).

However, few studies combined the CrTS and CvTS due to their differing basic approaches (Pantiwati, 2013; Seymour et al., 2003). According to Cottrell (2017), CrTS needed students to think deductive, realistic, systematic, and rational which have several aspects such as disposition, criteria, argument, reasoning, point of view, and procedures for applying criteria (Cottrell, 2017). These aspects were different from the CvTS approach, which comprises originality, elaboration, fluency, and flexibility (Lince, 2016). Lince (2016) CvTS approaches comprises of divergence, autistic, emotional, and natural and divergence thinking patterns. However, students' ability to participate in experiment activity is used to solve mixed approaches (Lince, 2016).

The Higher Order Thinking Laboratory (HOT Lab) has implemented the experiment model in the colleges and schools. HOT Lab model showed good results in students' achievement after using it as a "Corresponding author: adammalik@uinsgd.ac.id 
learning activity. The research indicated that the practice of competences building is good when used in more than once (Setiawan et al., 2018). However, it had several limitations associated with the steps and evaluations, therefore the HOT Lab model needs improvement, which can be carried out using the Multiple Skill Laboratory Activity Module (MSLAM).

MSLAM is a module developed to modify the various HOT Lab steps by adding two steps to increase CrTS and CvTS. The CrTS and CvTS were practiced using MSLAM with the effect analysed by carrying out a Multivariate test in accordance with Models and Gender. Analysis by gender is used to provide information on gender contribution in laboratory activity. This study aims to describe the improvement of students' critical-creative thinking skills after using MSLAM as a HOT Lab refinement module. Therefore, teachers in college or schools need to carry out learning more optimally.

\section{Research Question}

1. How do the experimental models of students' critical-creative thinking skills simultaneously contribute to their knowledge?

2. Does gender affect student's critical-creative thinking skills, which are simultaneously practiced?

\section{Materials and Methods}

This is a quantitative and experimental research with data consisting of students' critical and creative thinking skills in two groups. The physics contents taught in this study are electric current (El-Cr) and elasticity (Elc). The respondents in this study were 328 students divided into 10 subject groups. The first five groups also are known as the control groups, carried out the HOT Lab model, while the remaining five, which utilized the MSLAM model were in the experimental class. Groups A, B, C, D, and E comprises of students from the UIN Sunan Gunung Djati Bandung (Java), UIN Imam Bonjol Padang (Sumatra), UIN Alauddin Makasar (Sulawesi), IAIN Palangka Raya (Kalimantan), and IAIN Syech Nurjati Cirebon (Java), respectively. Each selected group subject has heterogeneous academic abilities with different habits and learning experience.

Data were collected using an essay test-form, which includes CvTS and CrTS. The CvTS test consists of four indicators modified through creative thinking from Almaeida (Almeida et al., 2008) and Alrubaie (Alrubaie and Daniel, 2014). Research techniques that are flexible, elaborating, and innovating. The CrTS test consists of seven indicators modified from Binkley (Binkley et al., 2012) and Tiruneh's (Tiruneh et al., 2017) research techniques: reasoning, interpreting, explaining, synthesizing, evaluating, and inferencing. Furthermore, all of the results were analysed using the normalized gain result of each subject's groups $\langle\mathrm{g}\rangle$ (Hake, 1999).

$\mathrm{N}$-gain scores are then used as the data source for multivariate tests, which consist of three parts that analyzed the experiments, gender, and combination between the experiments and gender. The experiment was used to analyze the influence of added syntax to the critical and creative thinking skills of students. While gender analysis aimed at seeing the contribution of gender in experiment-based learning.

\section{Results}

The results of this study consist of the Manova analysis, which influences each independent variable (experiment model, gender, and combination of both) and the dependent (CrTS and CvTS) in all subjects.

\section{Analysis of the experiment learning model}

The first analysis is used to determine how the experiment model influences students' CrTS and CvTS, which are simultaneously trained through different experimental activities, such as HOT-Lab for the control class and MSLAM for the experiment. Table 1,2 and 3 show the results of Manova analysis presented in the form of a multivariate test, Levene's Test of Equality of Error Variances, and Test of Between-Subject Effects. 
Malik, A. \& Ubaidillah, M. (2020). Students critical-creative thinking skill: A multivariate analysis of experiments and gender, International Journal of Cognitive Research in Science, Engineering and Education (IJCRSEE), (8), Special issue of Current Research and Trends in Cognitive Sciences 2020, 49-58.

Table 1

Multivariate test by Pillai's Trace method

\begin{tabular}{cccccc}
\hline Subjects & Group A & Group B & Group C & Group D & Group E \\
\hline Value & 0.305 & 0.395 & 0.275 & 0.352 & 0.521 \\
F & 15.81 & 8.973 & 5.487 & 7.46 & 19.047 \\
sig. & 0.000 & 0.000 & 0.001 & 0.000 & 0.000 \\
\hline
\end{tabular}

Based on Table 1, it can be concluded that the experimental models have a significant influence on CrTS and CvTS. This result is expressed by a p-value smaller than 0.05 in each test, which gives the overall conclusion that experimental model has a significant effect on CrTS and CvTS.

Table 2

Levene's Test of Equality of Error Variances

\begin{tabular}{ccccccccccc}
\hline Contents & \multicolumn{3}{c}{ El-Cr } & \multicolumn{1}{c}{ Elc } \\
\hline Group & A & B & C & D & E & A & B & C & D & E \\
CvTS & 0.026 & 0.113 & 0.175 & 0.175 & 0.105 & - & 0.048 & 0.135 & 0.048 & 0.000 \\
CrTS & 0.000 & 0.297 & 0.003 & 0.003 & 0.026 & - & 0.003 & 0.008 & 0.195 & 0.195 \\
\hline
\end{tabular}

Table 2 showed that students in the control and experiment classes are in an inhomogeneous group. Most of the scores are higher than 0.05 , in accordance with the score and significance values, therefore the data are homogeneous. This result showed that the student's score of CrTS and CVTS are in the control class using HOTs Lab model, while the experiment class produced different results using the MSLAM (Stichter et al., 2019). Meanwhile, the data classified in each competence, can improve CvTS using the MSLAM, because the average significance score is 0.091 . This result showed that the group's variant is relatively different, with an average CrTS significance score of 0.081 (Mertler and Reinhart, 2016). Table 3 shows the Test of Between-Subject Effects analysis, which was carried out to provide a detailed answer.

Table 3

Test of Between-Subject Effects

\begin{tabular}{|c|c|c|c|c|c|c|c|c|c|c|c|}
\hline \multirow{2}{*}{ Skills } & \multirow{2}{*}{$\frac{\text { Group }}{\text { Contents }}$} & \multicolumn{2}{|c|}{ A } & \multicolumn{2}{|c|}{ B } & \multicolumn{2}{|c|}{ C } & \multicolumn{2}{|c|}{ D } & \multicolumn{2}{|c|}{$\mathrm{E}$} \\
\hline & & $\mathrm{El}-\mathrm{Cr}$ & Elc & $\mathrm{El}-\mathrm{Cr}$ & Elc & $\mathrm{El}-\mathrm{Cr}$ & Elc & $\mathrm{El}-\mathrm{Cr}$ & Elc & $\mathrm{El}-\mathrm{Cr}$ & Elc \\
\hline \multirow{3}{*}{ CvTS } & Intercept & 0.000 & - & 0.000 & 0.000 & 0.000 & 0.000 & 0.000 & 0.000 & 0.000 & 0.000 \\
\hline & Experiment & 0.000 & - & 0.622 & 0.000 & 0.331 & 0.000 & 0.013 & 0.000 & 0.009 & 0.004 \\
\hline & Error & 0.057 & - & 0.115 & 0.074 & 0.104 & 0.051 & 0.082 & 0.064 & 0.06 & 0.07 \\
\hline \multirow{3}{*}{ CrTS } & Intercept & 0.000 & - & 0.000 & 0.000 & 0.000 & 0.000 & 0.000 & 0.000 & 0.000 & 0.000 \\
\hline & Experiment & 0.009 & - & 0.033 & 0.042 & 0.025 & 0.013 & 0.033 & 0.042 & 0.012 & 0.000 \\
\hline & Error & 0.060 & - & 0.057 & 0.082 & 0.078 & 0.055 & 0.057 & 0.082 & 0.083 & 0.079 \\
\hline
\end{tabular}

This test was used to determine the contribution of each experiment model that improved students' CrTS and CVTS. Table 3 shows an intercept value on each variable, which is less than 0.05 , which means that it is significant. Therefore, the experimental model, HOT Lab, and MSLAM contributed differently with a significant value of student achievement in each group (Cronk, 2017; Mertler and Vannatta, 2002).

In addition, there is a significant value that specifically illustrated the effect of the experiment model on the dependent variable. Furthermore, the significant value of the model, which is less than 0.05 , positively improved the CVTS in the Elc content. This result is different from the increase in CvTS on El-Cr 
content with a significance value greater than 0.05 in two groups.

\section{Gender analysis}

This was carried out to acquire an overview of gender effect in increasing students' CvTS and CrTS. A total of 328 students comprising 61 males and 267 females were used to carry out this research. The first analysis is multivariate test significance, as shown in Table 4.

Table 4

Multivariate test by Pillai's Trace method

\begin{tabular}{cccccc}
\hline Subjects & Group A & Group B & Group C & Group D & Group E \\
\hline Value & 0.065 & 0.038 & 0.048 & 0.019 & 0.127 \\
F & 2.522 & 0.547 & 0.735 & 0.265 & 2.537 \\
sig. & 0.087 & 0.702 & 0.572 & 0.899 & 0.048 \\
\hline
\end{tabular}

Table 4 shows that the overall independent variable, or gender, did not affect the values of CVTS and CrTS at a significance value above 0.05 in each group. Therefore, this indicates that gender does not influence the significant increase of CVTS and CrTS. Meanwhile, the differences in student scores can be analysed by their gender, as shown in Table 5 .

Table 5

Levene's Test of Equality of Error Variances

\begin{tabular}{cccccccccccc} 
Contents & \multicolumn{1}{c}{ El-Cr } & \multicolumn{1}{c}{ Elc } \\
\hline Group & A & B & C & D & E & A & B & C & D & E \\
CvTS & 0.097 & 0.641 & 0.641 & 0.591 & 0.186 & - & 0.05 & 0.05 & 0.698 & 0.153 \\
CrTS & 0.309 & 0.157 & 0.157 & 0.328 & 0.904 & - & 0.362 & 0.362 & 0.75 & 0.361 \\
\hline
\end{tabular}

Table 5 shows that the most significant value is higher than 0.05 , which means that the scores of CvTS and CrTS are definitely different (Stichter et al., 2019) due to students' efficacy and anxiety in the learning process (Assan and Sarfo, 2015). This is similar to the studies carried out by (Chang, S., and Cho, 2013; Hill et al., 2016), which stated that female students are more anxious than males, especially in math.

Table 6

Test of Between-Subject Effects

\begin{tabular}{ccccccccccccc}
\hline \multirow{2}{*}{ Skills } & Group & \multicolumn{2}{c}{ A } & \multicolumn{2}{c}{ B } & \multicolumn{2}{c}{ C } & \multicolumn{2}{c}{ D } & \multicolumn{2}{c}{ E } \\
\cline { 2 - 12 } & Contents & El-Cr & Elc & El-Cr & Elc & El-Cr & Elc & El-Cr & Elc & El-Cr & Elc \\
\hline \multirow{3}{*}{ CvTS } & Intercept & 0.000 & - & 0.000 & 0.000 & 0.000 & 0.000 & 0.000 & 0.000 & 0.000 & 0.000 \\
& Gender & 0.799 & - & 0.565 & 0.222 & 0.564 & 0.187 & 0.729 & 0.968 & 0.026 & 0.052 \\
& Error & 0.073 & - & 0.115 & 0.061 & 0.105 & 0.066 & 0.091 & 0.061 & 0.061 & 0.075 \\
& Intercept & 0.000 & - & 0.000 & 0.000 & 0.000 & 0.000 & 0.000 & 0.000 & 0.000 & 0.000 \\
\multirow{2}{*}{ CrTS } & Gender & 0.029 & - & 0.923 & 0.616 & 0.779 & 0.748 & 0.534 & 0.501 & 0.552 & 0.783 \\
& Error & 0.060 & - & 0.110 & 0.087 & 0.059 & 0.085 & 0.083 & 0.087 & 0.090 & 0.132 \\
\hline
\end{tabular}


Malik, A. \& Ubaidillah, M. (2020). Students critical-creative thinking skill: A multivariate analysis of experiments and gender, International Journal of Cognitive Research in Science, Engineering and Education (IJCRSEE), (8), Special issue of Current Research and Trends in Cognitive Sciences 2020, 49-58.

Table 6 shows that the intercept value on each variable is less than a significance of 0.05. (Bergold et al., 2017) stated that gender contribution is insignificant because the average score is 0.457 for CvTS and 0.607 for CrTS. According to (Cronk, 2017; Mertler and Vannatta, 2002), gender contribution is significant when the score is less than 0.05 . This result is particularly accurate at average errors of $8.81 \%$ and $7.87 \%$ for CrTS and CvTS, respectively. This is in accordance with the socio-scientific research and principles of correctness which amounted to $91.19 \%$ and $92.13 \%$ for critical and creative thinking skills.

\section{Combined analysis of experiment types and gender}

The last analysis reviews the simultaneous contributions of the experimental and gender models to improve CrTS and CvTS.

\section{Table 7}

Multivariate test by Pillai's Trace method

\begin{tabular}{cccccccccccc}
\hline Group & \multicolumn{2}{c}{ A } & \multicolumn{2}{c}{ B } & \multicolumn{2}{c}{ C } & \multicolumn{2}{c}{ D } & & E \\
\hline d-factor $^{*}$ & exp & gen & Exp & gen & exp & gen & exp & gen & exp & gen \\
Value & 0.316 & 0.081 & 0.397 & 0.042 & 0.49 & 0.275 & 0.351 & 0.018 & 0.522 & 0.128 \\
F & 16.430 & 3.110 & 8.898 & 0.592 & 0.738 & 5.412 & 7.312 & 0.253 & 18.828 & 2.530 \\
sig. & 32.867 & 0.051 & 0.000 & 0.670 & 0.570 & 0.001 & 0.000 & 0.907 & 0.000 & 0.048 \\
\hline
\end{tabular}

* $d$-factor is different factors that used in analyse, exp = experiment type, gen = gender

Table 7 shows a variety of spreads with significant values in the experiment and gender models of group A higher than 0.05. In group B, the experiment and gender models are significant and insignificant at values of 0.00 and 0.67 . Furthermore, in group $C$, the experiment and gender models are insignificant and significant at values of 0.57 and 0.001 . In group $\mathrm{D}$, the experiment model provides a significant influence, as opposed to gender. The last group shows a significant influence on both aspects. Therefore, it can be concluded that the analyzed student competencies are separately carried out due to the varying basic point of view (Berglund and Gericke, 2016; Garcia and Mayorga, 2018; Kottorp et al., 2019).

\section{Table 8}

Levene's Test of Equality of Error Variances

\begin{tabular}{cccccccccccc}
\hline Content & \multicolumn{4}{c}{ El-Cr } & \multicolumn{1}{c}{ Elc } \\
\hline Group & A & B & C & D & E & A & B & C & D & E \\
CvTS & 0.000 & 0.311 & 0.387 & 0.200 & 0.042 & - & 0.050 & 0.076 & 0.493 & 0.189 \\
CrTS & 0.025 & 0.039 & 0.069 & 0.465 & 0.259 & - & 0.123 & 0.070 & 0.188 & 0.000 \\
\hline
\end{tabular}

The analysis of homogeneity indicates that there are differences in CrTS and CvTS of the experimental and control classes. In CvTS, Levene's Test's average score is significant because it is 0.194 greater than 0.05 . This means, that the experimental and gender models are different in accordance with students' scores. The same result is also shown by CrTS average score with 0.138 above 0.05 and different from their experiment and gender models (Stichter et al., 2019). 
Malik, A. \& Ubaidillah, M. (2020). Students critical-creative thinking skill: A multivariate analysis of experiments and gender, International Journal of Cognitive Research in Science, Engineering and Education (IJCRSEE), (8), Special issue of Current Research and Trends in Cognitive Sciences 2020, 49-58.

Table 9

Test of Between-Subject Effects

\begin{tabular}{ccccccccccccc}
\hline \multirow{2}{*}{ Skills } & Group & \multicolumn{2}{c}{$\mathrm{A}$} & \multicolumn{2}{c}{$\mathrm{B}$} & \multicolumn{2}{c}{$\mathrm{C}$} & \multicolumn{2}{c}{$\mathrm{D}$} & \multicolumn{2}{c}{$\mathrm{E}$} \\
\cline { 2 - 12 } & Contents & $\mathrm{El}-\mathrm{Cr}$ & $\mathrm{Elc}$ & $\mathrm{El}-\mathrm{Cr}$ & $\mathrm{Elc}$ & $\mathrm{El}-\mathrm{Cr}$ & $\mathrm{Elc}$ & $\mathrm{El}-\mathrm{Cr}$ & $\mathrm{Elc}$ & $\mathrm{El}-\mathrm{Cr}$ & $\mathrm{Elc}$ \\
\hline \multirow{3}{*}{ CvTS } & Intercept & 0.000 & - & 0.000 & 0.000 & 0.000 & 0.000 & 0.000 & 0.000 & 0.000 & 0.000 \\
& Experiment & 0.968 & - & 0.575 & 0.169 & 0.644 & 0.282 & 0.762 & 0.545 & 0.013 & 0.061 \\
& Error & 0.000 & - & 0.633 & 0.000 & 0.366 & 0.019 & 0.014 & 0 & 0.005 & 0.005 \\
& Intercept & 0.000 & - & 0.000 & 0.000 & 0.000 & 0.000 & 0.000 & 0.000 & 0.000 & 0.000 \\
CrTS & Experiment & 0.015 & - & 0.882 & 0.575 & 0.411 & 0.54 & 0.926 & 0.459 & 0.634 & 0.976 \\
& Error & 0.005 & - & 0.035 & 0.042 & 0.000 & 0.022 & 0.035 & 0.042 & 0.013 & 0.000 \\
\hline
\end{tabular}

Table 9 shows an explicit analysis of the contributions of two independent variables against two dependent variables simultaneously. It provides the same intercept value in each group indicating that the experiment and gender models are capable of significantly changing each subject group's value for the improvement of CrTS, and CvTS.

Furthermore, the overall data on Table 9 shows that gender does not significantly improve CrTS and CvTS, as opposed to the experiment model. Lastly, the data error, of the combination analysis provides a relatively small error with an average error of $7.01 \%$ and $7.53 \%$ for CrTS and CvTS. This shows that the method used in this research has an acceptance rate of $92.99 \%$ and $92.47 \%$ for increasing $\mathrm{CrTS}$ and CvTS.

\section{Discussion}

The research results showed that experimental model has significant affect to improve student's CrTS dan CvTS simultaneously. This is unique because these two competencies have different characteristics from one another. CrTS are convergent thinking skills, meaning that if they are trained students must be able to carry out various analyzes of facts and draw conclusions from the multiple facts found. In contrast to CvTS which have divergent characteristics where students are trained to have high curiosity, elaboration, flexibility and tend to rely on imagination. Even though these two abilities do not collide with each other in a cognitive context, in carrying out practicum activities using the MSLAM model, these two abilities can be trained simultaneously. Refer to the model syntax and practicum steps in the MSLAM model, which can develop CrTS and CVTS.

The development of creative and critical thinking skills through elasticity and electricity practicum activities using MSLAM can be viewed from several stages. The stages of practicum activities that can train and develop aspects of critical thinking skills include real-world problems, experimental questions, brainstorming, conceptual questions, prediction, analysis, evaluation, and reflection. Creative thinking skills that can be developed through various stages of MSLAM practicum include brainstorming, proposing alternative ideas, exploration, and measurement. Critical and creative thinking skills can be developed through brainstorming (Chang et al., 2015). The activity of proposing alternative ideas as part of divergent thinking can give birth to new methodologies, generate new ideas, and students' scientific practice. (Abraham, 2013; Antink-Meyer and Lederman, 2015).

The explanation of these findings is due to the habits of students while carrying out experiments. Based on a study conducted by Lin et al. (2004), another aspect related to the scientific process is the logic of science as a form of logical thinking. Therefore, laboratory activities also provide a rich context for using shared logical thinking between CvTS and CrTS (Koray and Köksal, 2009). Thus, from the point of view of activity steps, it can be stated that MSLAM can train CrTS and CvTS.

The other side, Elc is part of the mechanical content where students carried out mechanical experiments more often than electronica experiments since middle school. It is different from the implementation of $\mathrm{El}-\mathrm{Cr}$ experiment, which is often ignored, and made them possess less level of their CVTS. This finding is consistent with the studies carried out by (Harris and de Bruin, 2018; Irjayanti and 
Azis, 2017; Lucas, 2016). In the review of the CrTS, it is apparent that all the subject groups in each content have a significance value of less than 0.05 , with MSLAM providing more effect to CrTS than HOTs Lab. When the results were reviewed, this study obtained the average error rate for CvTS $7.52 \%$ and CrTS 7.03\% which is relatively small for the research group socio-scientific (Nuijten et al., 2016; Rahman et al., 2017; Vázquez-Cano et al., 2017). Therefore, it can be concluded that the addition of HOT Lab model's several steps has succeeded in increasing students CVTS and CrTS simultaneously.

In other side, gender analysis showed an insignificant influence on improving CVTS and CrTS. According to previous studies, students' syntax, level of difficulty, habit, and motivation are also some of the reasons for the insignificant values. In the performance process, male students tend to perform better than their female counterparts. However, in the data processing, analysing and reporting stages, the reverse was the case. This finding is also reinforced by the results of previous studies which show that generallly there is no difference in ability between male and female students, but only in a few conditions (Adolphus and Omeodu, 2016; Aeschlimann et al., 2016; Bećirović, 2017; Brodahl et al., 2011; Crymble, 2016; Master et al., 2017; Putri et al., 2018; Sayed and Mohamed, 2013). This result is different from previous research in that male students tend to have better analytical thinking skills than female students. Lin et al. (2004) stated that CvTS and CrTS as higher-order thinking skills are related to other variables such as age, cognitive level and field of study. The results also contradict the statement that female students have higher levels of CvTs than male students at the university level (Matud, Rodríguez, and Grande, 2007); female students performed better on divergent thinking tests, while male abilities were superior in insightful problem-solving tasks (Lin et al., 2012); In divergent thinking, men have a stronger declarative memory, while women have advantages in the theory of mind, social perception, speech processing and reference processing (Abraham et al., 2014); male students have higher creativity than female students when they produce the same output (Proudfoot, Kay, and Koval, 2015).

These findings have a relatively high level of accuracy based on the error value that provide a relatively small error value of $7.52 \%$ and $7.03 \%$ for the experimental models of CvTS, and CrTS. Meanwhile, using the gender model, it produced $7.87 \%$ and $8.81 \%$ for CvTS, and CrTS, with $7.53 \%$ and 7.01 for the simultaneous models of experiment and gender to CvTS, and CrTS (Nuijten et al., 2016; Rahman et al., 2017; Vázquez-Cano et al., 2017). Therefore, in conclusion, MSLAM has the ability to adapt two thinking skills at once. Therefore, efforts are needed to take a wider implementation to determine the effectiveness of this model.

The limitation found in this study is in combination analysis methods, which were carried out by combining the experiment and gender models, which are the external and internal factors of students. These results are biased because gender influences students' learning interests, especially their experimental activities. Therefore, subsequent studies need to be carried out for students' tendency factors based on gender, to obtain more accurate measurement results.

\section{Conclusions}

The results showed that experimental learning using MSLAM can improve CrTS and CvTS simultaneously. MANOVA test suggests that the MSLAM contributes more significantly to the HOT Lab. Besides, gender analysis showed an insignificant influence on improving CvTS and CrTS. These contributions provide a relatively small error value of $7.52 \%$ and $7.03 \%$ for the experimental models of CvTS, and CrTS. Meanwhile, using the gender model, it produced $7.87 \%$ and $8.81 \%$ for CVTS, and CrTS, with $7.53 \%$ and 7.01 for the simultaneous models of experiment and gender to CvTS, and CrTS. Therefore, in conclusion, MSLAM can adapt two thinking skills at once. Therefore, efforts are needed to take a broader implementation to determine the effectiveness of this model.

\section{Acknowledgments}

This research was financially supported by the Ministry of Religious Affairs of the Republic Indonesia via Directorate General of Islamic Education through grant 1967 in 2019 regarding recipients of global/ international applied research assistance in fiscal 2019 for facilitating and financing this research.

\section{Conflict of interests}

The authors declare no conflict of interest. 
Malik, A. \& Ubaidillah, M. (2020). Students critical-creative thinking skill: A multivariate analysis of experiments and gender, International Journal of Cognitive Research in Science, Engineering and Education (IJCRSEE), (8), Special issue of Current Research and Trends in Cognitive Sciences 2020, 49-58.

\section{References}

Abraham, A. (2013). The promises and perils of the neuroscience of creativity. Frontiers in Human Neuroscience, 7(246), 1-9. https://doi.org/10.3389/fnhum.2013.00246

Abraham, A., Thybusch, K., Pieritz, K., \& Hermann, C. (2014). Gender differences in creative thinking: behavioral and fMRI findings. Brain imaging and behavior, 8(1), 39-51. https://doi.org/10.1007/s11682-013-9241-4

Adolphus, T., \& Omeodu, D. (2016). Effects of gender and collaborative learning approach on students' conceptual understanding of electromagnetic induction. Journal of Curriculum and Teaching, 5(1), 78-86. https://doi.org/10.5430/jct.v5n1p78

Aeschlimann, B., Herzog, W., \& Makarova, E. (2016). How to foster students' motivation in mathematics and science classes and promote students' STEM career choice. A study in Swiss high schools. International Journal of Educational Research, 79, 31-41. https://doi.org/10.1016/.i.jer.2016.06.004

Almeida, L. S., Prieto, L. P., Ferrando, M., Oliveira, E., \& Ferrandiz, C. (2008). Torrance Test of Creative Thinking: The question of its construct validity. Thinking Skills and Creativity, 3(1), 53-58. https://doi.org/https://doi.org/10.1016/i.tsc.2008.03.003

Alrubaie, F., \& Daniel, E. G. (2014). Developing a creative thinking test for Iraqi physics students. International Journal of Mathematics and Physical Sciences Research, 2(1), 80-84. Retrieved from https://researchpublish.com/issue/ IJMPSR/Issue-1-April-2014-September-2014

Antink-Meyer, A., \& Lederman, N. G. (2015). Creative Cognition in Secondary Science: An exploration of divergent thinking in science among adolescents. International Journal of Science Education, 37(10), 1547-1563. https://doi.org/10.1080/ 09500693.2015 .1043599

Assan, E. A., \& Sarfo, J. O. (2015). Piagetian Conservation Tasks in Ghanaian Children: the Role of Geographical Location, Gender and Age Differences. European Journal of Contemporary Education, 12(2), 137-149. https://doi.org/10.13187/ ejced.2015.12.137

Bean, J. C. (2011). Engaging Ideas: The Professor's Guide to Integrating Writing, Critical Thinking, and Active Learning in the Classroom. In Jossey-Bass. John Wiley \& Son.

Bećirović, S. (2017). The relationship between gender, motivation and achievement in learning english as a foreign language. European Journal of Contemporary Education, 6(2), 210-220. https://doi.org/10.13187/ejced.2017.2.210

Berglund, T., \& Gericke, N. (2016). Separated and integrated perspectives on environmental, economic, and social dimensions - an investigation of student views on sustainable development. Environmental Education Research, 22(8), 11151138. https://doi.org/10.1080/13504622.2015.1063589

Bergold, S., Wendt, H., Kasper, D., \& Steinmayr, R. (2017). Academic competencies: Their interrelatedness and gender differences at their high end. Journal of Educational Psychology, 109(3), 439-449. https://doi.org/10.1037/edu0000140

Binkley, M., Erstad, O., Herman, J., Raizen, S., Ripley, M., Miller-Ricci, M., \& Rumble, M. (2012). Defining twenty-first century skills. In Assessment and teaching of $21^{\text {st }}$ century skills (pp. 17-66). Springer, Dordrecht. https://doi.org/10.1007/97894-007-2324-5_2

Brodahl, C., Hadjerrouit, S., \& Kristian Hansen, N. (2011). Collaborative writing with web 2.0 technologies: Education students' perceptions. Journal of Information Technology Education: Innovations in Practice, 10, 073-103. https://doi. org/10.28945/1384

Bustami, Y., \& Corebima, A. D. (2017). The Effect of JiRQA Learning Strategy on Critical Thinking Skills of Multiethnic Students in Higher Education, Indonesia. International Journal of Humanities Social Sciences and Education, 4(3), 13-22. https://doi.org/http://dx.doi.org/10.20431/2349-0381.0403003

Chang, S., \& Cho, S. (2013). Development and validation of the Korean mathematics anxiety rating scale for college students. Journal Of the Korean Data Analysis Society, 15(4), 1955-1969.

Chang, Y., Li, B. Di, Chen, H. C., \& Chiu, F. C. (2015). Investigating the synergy of critical thinking and creative thinking in the course of integrated activity in Taiwan. Educational Psychology, 35(3), 341-360. https://doi.org/10.1080/01443410.20 14.920079

Cottrell, S. (2017). Critical thinking skills: Effective analysis, argument and reflection. Macmillan International Higher Education.

Cronk, B. C. (2017). How to Use SPSS®: A Step-By-Step Guide to Analysis and Interpretation (10 thed.). Routledge.

Crymble, A. (2016). Identifying and removing gender barriers in open learning communities: The programming historian. Blended Learning in Practice, 2016 (July 2012), 49-60.

Fuad, N. M., Zubaidah, S., Mahanal, S., \& Suarsini, E. (2017). Improving Junior High Schools' Critical Thinking Skills Based on Test Three Different Models of Learning. International Journal of Instruction, 10(1), 101-116. https://doi.org/10.12973/ iij.2017.1017a

Garcia, N. M., \& Mayorga, O. J. (2018). The threat of unexamined secondary data: A critical race transformative convergent mixed methods. Race Ethnicity and Education, 21(2), 231-252. https://doi.org/10.1080/13613324.2017.1377415

Hadi, S. A., Susantini, E., \& Agustini, R. (2018). Training of Students' Critical Thinking Skills through the implementation of a Modified Free Inquiry Model. Journal of Physics: Conference Series, 947(1), 012063. https://doi.org/10.1088/1742$6596 / 947 / 1 / 012063$

Hake, R.R., \& Reece, J. (1999). Analyzing Change/Gain Scores. American Eduational Research Asociation's Divisions, Measurement and Reseacrh Methoology, 1-4. Retreived from https://www.semanticscholar.org/paper/ANALYZINGCHANGE\%2FGAIN-SCORES*\%E2\%80\%A0-Hake-Reece/ee433f272764045eede29180e06f62c963dcc4a2

Harris, A., \& de Bruin, L. R. (2018). Training teachers for twenty-first century creative and critical thinking: Australian implications from an international study. Teaching Education, 29(3), 234-250. https://doi.org/10.1080/10476210.2017.1384802

Hastuti, P. W., Nurohman, S., \& Setianingsih, W. (2018). The Development of Science Worksheet Based on Inquiry Science Issues to Improve Critical Thinking and Scientific Attitude. Journal of Physics: Conference Series, 1097(1), 012004. https://doi.org/10.1088/1742-6596/1097/1/012004

Hill, F., Mammarella, I. C., Devine, A., Caviola, S., Passolunghi, M. C., \& Szücs, D. (2016). Maths anxiety in primary and secondary school students: Gender differences, developmental changes and anxiety specificity. Learning and Individual Differences, 48, 45-53. https://doi.org/10.1016/j.lindif.2016.02.006

Irjayanti, M., \& Azis, A. M. (2017). Implementing technology in creative industry (Benchmarking study in developed countries). 
Malik, A. \& Ubaidillah, M. (2020). Students critical-creative thinking skill: A multivariate analysis of experiments and gender, International Journal of Cognitive Research in Science, Engineering and Education (IJCRSEE), (8), Special issue of Current Research and Trends in Cognitive Sciences 2020, 49-58.

Advanced Science Letters, 23(9), 8113-8118. https://doi.org/10.1166/asl.2017.9845

Koray, Ö., \& Köksal, M. S. (2009). The effect of creative and critical thinking based laboratory applications on creative and logical thinking abilities of prospective teachers. In Asia-Pacific Forum on Science Learning \& Teaching, 10(1), 1.

Kottorp, A., Keehn, M., Hasnain, M., Gruss, V., \& Peterson, E. (2019). Instrument Refinement for Measuring Self-Efficacy for Competence in Interprofessional Collaborative Practice: Development and Psychometric Analysis of IPECC-SET 27 and IPECC-SET 9. Journal of Interprofessional Care, 33(1), 47-56. https://doi.org/10.1080/13561820.2018.1513916

Lin, W. L., Hsu, K. Y., Chen, H. C., \& Wang, J. W. (2012). The relations of gender and personality traits on different creativities: A dual-process theory account. Psychology of Aesthetics, Creativity, and the Arts, 6(2), 112-123. https://doi.org/10.1037/ a002624

Lince, R. (2016). Creative thinking ability to increase student mathematical of junior high school by applying models numbered heads together. Journal of Education and Practice, 7(6), 206-212. Retrieved from https://files.eric.ed.gov/fulltext/ EJ1092494.pdf

Lisdiani, Sahidah, S. A., Setiawan, A., Suhandi, A., Malik, A., \& Safitri, D. (2019). The Implementation of HOT Lab Activity to Improve Students Critical Thinking Skills. Journal of Physics Conference Series, 1204(1), 012033. Retrieved from https://iopscience.iop.org/article/10.1088/1742-6596/1204/1/012033/meta

Lucas, B. (2016). A five-dimensional model of creativity and its assessment in schools. Applied Measurement in Education, 29(4), 278-290. https://doi.org/10.1080/08957347.2016.1209206

Malik, A., Yuliani, Y., Rochman, C., Zakwandi, R., Ismail, A., \& Ubaidillah, M. (2020). Optimizing students critical thinking skills related to heat topics through the model of content, context, connection, researching, reasoning, reflecting (3C3R). Journal of Physics: Conference Series, 1521(2), 022001. https://doi.org/10.1088/1742-6596/1521/2/022001

Malik, A, Setiawan, A., Suhandi, A., Permanasari, A., Samsudin, A., Safitri, D., Lisdiani, S. A. S., Sapriadil, S., \& Hermita, N. (2018). Using hot lab to increase pre-service physics teacher's critical thinking skills related to the topic of RLC circuit. Journal of Physics: Conference Series, 1013(1), 012023. https://doi.org/10.1088/1742-6596/1013/1/012023

Malik, A., Nuraeni, Y., Samsudin, A., \& Sutarno. (2019). Creative thinking skills of students on harmonic vibration using model Student Facilitator And Explaining ( SFAE ). Jurnal IImiah Penidikan Fisika Al-BiRuNi, 08(1), 77-88. https://doi. org/10.24042/jipfalbiruni.v8i1.3056

Martaida, T., Bukit, N., \& Ginting, E. M. (2017). The effect of discovery learning model on student's critical thinking and cognitive ability in junior high school. IOSR Journal of Research \& Method in Education (IOSR-JRME), 7(6), 1-8. https://doi. org/10.9790/7388-0706010108

Master, A., Cheryan, S., Moscatelli, A., \& Meltzoff, A. N. (2017). Programming experience promotes higher STEM motivation among first-grade girls. Journal of experimental child psychology, 160, 92-106. https://doi.org/10.1016/j.jecp.2017.03.013

Matud, M. P., Rodríguez, C., \& Grande, J. (2007). Gender differences in creative thinking. Personality and individual differences, 43(5), 1137-1147. https://doi.org/10.1016/j.paid.2007.03.006

Mertler, C. A., \& Reinhart, R. V. (2016). Advanced and multivariate statistical methods: Practical application and interpretation. Taylor \& Francis. Retrieved from http://bayes.acs.unt.edu:8083/BayesContent/class/Jon/ResourcesWkshp/ DecisionTree_MertlerVannatta.pdf

Mertler, C. A., \& Vannatta, R. A. (2002). A guide to multivariate techniques. Advanced and Multivariate Statistical Methods. $2^{\text {nd }}$ ed. Los Angeles, CA: Pyrczak Publishing.

Muhlisin, A., Susilo, H., Amin, M., \& Rohman, F. (2016). Improving critical thinking skills of college students through RMS model for learning basic concepts in science. Asia-Pacific Forum on Science Learning and Teaching, 17(1), 1-24.

Nasir, M. (2018). Influence of Project-Based Learning Model that Aided Matrix Laboratory toward Creative Thinking Skills Viewed from College Student's Science Generic Skills. Indonesian Journal of Science and Education, 2(2), 100-106, 161-167. https://doi.org/10.31002/ijose.v2i2.779

Nugraha, M. G., Kaniawati, I., Rusdiana, D., \& Kirana, K. H. (2016, February). Combination of inquiry learning model and computer simulation to improve mastery concept and the correlation with critical thinking skills (CTS). In AIP Conference Proceedings (Vol. 1708, No. 1, p. 070008). AIP Publishing LLC. https://doi.org/10.1063/1.4941181

Nuijten, M. B., Hartgerink, C. H., van Assen, M. A., Epskamp, S., \& Wicherts, J. M. (2016). The prevalence of statistical reporting errors in psychology (1985-2013). Behavior research methods, 48(4), 1205-1226. https://doi.org/10.3758/ s13428-015-0664-2

Pantiwati, Y. (2013). Authentic assessment for improving cognitive skill, critical-creative thinking and meta-cognitive awareness. Journal of Education and Practice, 4(14), 1-9. Retrieved from https://www.iiste.org/Journals/index.php/JEP/article/ view/6790

Proudfoot, D., Kay, A. C., \& Koval, C. Z. (2015). A gender bias in the attribution of creativity: Archival and experimental evidence for the perceived association between masculinity and creative thinking. Psychological Science, 26(11), 1751-1761. https://doi.org/10.1177/095679761559873

Putri, A. U., Rusyati, L., \& Rochintaniawati, D. (2018). The Impact of Problem-Solving Model on Students' Concept Mastery and Motivation in Learning Heat Based on Gender. Journal of Science Learning, 1(2), 71-76. https://doi.org/10.17509/ jsl.v1i2.9793

Quieng, M. C., Lim, P. P., \& Lucas, M. R. D. (2015). 21st Century-Based Soft Skills: Spotlight on Non-Cognitive Skills in a Cognitive-Laden Dentistry Program. European Journal of Contemporary Education, 11(1), 72-81. https://doi. org/10.13187/ejced.2015.11.72

Rahman, M. A., Sainu, M. N., \& Asfah, I. (2017, September). Revisiting the Linguistic Errors in the Writing of the Students Majoring in English. In $2^{\text {nd }}$ International Conference on Education, Science, and Technology (ICEST 2017). Atlantis Press. https://doi.org/10.2991/icest-17.2017.53

Saputri, A. C., SAjidan, Rinanto, Y., Afandi, \& Prasetyanti, N. M. (2019). Improving Students' Critical Thinking Skills in CellMetabolism Learning Using Stimulating Higher Order Thinking Skills Model. International Journal of Instruction, 12(1), 327-342. Retrieved from https://files.eric.ed.gov/fulltext/EJ1201357.pdf

Sari, D. M., Ikhsan, M., \& Abidin, Z. (2018, September). The development of learning instruments using the creative problemsolving learning model to improve students' creative thinking skills in mathematics. In Journal of Physics: Conference Series (Vol. 1088, p. 012018). https://doi.org/10.1088/1742-6596/1088/1/012018 
Malik, A. \& Ubaidillah, M. (2020). Students critical-creative thinking skill: A multivariate analysis of experiments and gender, International Journal of Cognitive Research in Science, Engineering and Education (IJCRSEE), (8), Special issue of Current Research and Trends in Cognitive Sciences 2020, 49-58.

Sayed, E. M., \& Mohamed, A. H. H. (2013). Gender Differences in Divergent Thinking: Use of the Test of Creative ThinkingDrawing Production on an Egyptian Sample. Creativity Research Journal, 25(2), 222-227. https://doi.org/10.1080/10 400419.2013.783760

Seranica, C., Purwoko, A. A., \& Hakim, A. (2018). Influence of Guided Inquiry Learning Model to Critical Thinking Skills. IOSR Journal of Research \& Method in Education, 8(1), 28-31. https://doi.org/10.9790/7388-0801022831

Setiawan, A., Malik, A., Suhandi, A., \& Permanasari, A. (2018, February). Effect of higher order thinking laboratory on the improvement of critical and creative thinking skills. In IOP Conference Series: Materials Science and Engineering, 306(1), pp. 1-7. https://doi.org/10.1088/1757-899X/306/1/012008

Seymour, B., Kinn, S., \& Sutherland, N. (2003). Valuing both critical and creative thinking in clinical practice: narrowing the research-practice gap?. Journal of Advanced Nursing, 42(3), 288-296. https://doi.org/10.1046/j.13652648.2003.02618.x

Stichter, J. P., Herzog, M. J., Malugen, E., \& Schoemann, A. M. (2019). Influence of homogeneity of student characteristics in a group-based social competence intervention. School Psychology, 34(1), 64. https://doi.org/10.1037/spq0000261

Suardana, I. N., Redhana, I. W., Sudiatmika, A. A., \& Selamat, I. N. (2018). Students' Critical Thinking Skills in Chemistry Learning Using Local Culture-Based 7E Learning Cycle Model. International Journal of Instruction, 11(2), 399-412. https://doi.org/10.12973/iii.2018.11227a

Tiruneh, D. T., Cock, M. De, Weldeslassie, A. G., Elen, J., \& Janssen, R. (2017). Measuring Critical Thinking in Physics : Development and Validation of a Critical Thinking Test in Electricity and Magnetism. International Journal of Science and Mathematics Education, 15, 663-682. https://doi.org/10.1007/s10763-016-9723-0

Vázquez-Cano, E., González, A. I. H., \& Sáez-López, J. M. (2017). An analysis of the orthographic errors found in university students' asynchronous digital writing. Journal of Computing in Higher Education, 31(1), 1-20.

Wang, J., Guo, D., \& Jou, M. (2015). A study on the effects of model-based inquiry pedagogy on students' inquiry skills in a virtual physics lab. Computers in Human Behavior, 49, 658-669. https://doi.org/10.1016/j.chb.2015.01.043

Weatherspoon, D. L., Phillips, K., \& Wyatt, T. H. (2015). Effect of electronic interactive simulation on senior bachelor of science in nursing students' critical thinking and clinical judgment skills. Clinical Simulation in Nursing, 11(2), 126-133, 126133. https://doi.org/10.1016/J.ECNS.2014.11.006

Yang, S. C., \& Lin, W. C. (2004). The relationship among creative, critical thinking and thinking styles in Taiwan high school students. Journal of Instructional Psychology, 31(1), 33-45.

Zaini, M., Kaspul, \& Rezeki, A. (2018). Hasil Belajar dan Keterampilan Berpikir Kritis Siswa SMA pada Pembelajaran Biologi menggunakan Model Inkuiri. [Learning Results and Critical Thinking Skills SMA On Biology Learning Using Inquiry Model]. BIOEDUKASI: Jurnal Pendidikan Biologi, 11(1), 17-22. https://jurnal.uns.ac.id/bioedukasi/article/view/19732 